\title{
THE GERMANIC FOURTH CLASS OF WEAK VERBS
}

The formation of Go. fullnō-, 3rd pl. fullnand 'become full' cannot be separated from that of Vedic prnấ-, 3rd pl. prnánti 'fill'. It has long been recognized that the two paradigms cannot be identified, however.

From a formal point of view, the expected stem form in Germanic should be *fullo-, with loss of the nasal and gemination of the preceding consonant. The attested verb is a denominative formation, derived from fulls 'full' < *plHnós.

From a semantic point of view, the verbs of the fourth weak class are intransitives, which is contrary to what can be expected on the basis of the older Indo-European languages. This requires an explanation.

It is probable that the nasal was always assimilated to a preceding consonant before the stress, cf. especially OHG storrēn 'stand out' beside stornēn 'be rigid', where the nasal was apparently restored, similarly sterro beside sterno 'star', ferro 'far' beside firni 'old', and swimman 'swim', Old Irish do-seinn 'pursues'. As it is improbable that the nasal suffix was generalized on the basis of vocalic roots only, the fourth class of weak verbs must have originated from an extension of the suffix to stressed roots before the nasal assimilation (Kluge's law, cf. Kortlandt 1991).

When we disregard the denominative verbs, the Gothic evidence for the fourth weak class is limited to the following material: aflifnan 'be left', dis-skritnan 'become torn', us-gutnan 'to be poured out', fra-lusnan 'be lost', ga-luknan 'be shut up', and-bundnan 'become unbound', ga-paursnan 'become dry', us-bruknan 'be broken', af-taurnan 'be torn away', ga-skaidnan 'become parted', ga-waknan 'awake'. It thus appears that the formation represents a nasal present derived from a middle root aorist with zero grade vocalism. This brings us to the problem of the aorist in Germanic.

Elsewhere (1989) I have argued that the endings of the Germanic weak preterit reflect the root aorist ${ }^{*} d \bar{e}-<* d h \bar{e}-$ and that in order to 
explain OE dyde 'did' we must assume that $3 \mathrm{rd}$ pl. *dédunp replaced earlier *dunp. The latter form is important because it has zero grade vocalism in the stressed syllable. It suggests a paradigm with fixed stress, unlike Go. stō $p$, OE stōdon 'he, they stood', which reflect a more recent paradigm with mobile stress. In fact, the previous existence of a 3rd pl. form *stunp provides the motivation for the creation of the form *stōdunp. The Verner alternation in Go. stōop, OE stōdon suggests an early date for this analogical development.

The paradigm of *de-, $3 \mathrm{rd} \mathrm{pl.} \mathrm{*dunp} \mathrm{is} \mathrm{strongly} \mathrm{reminiscent} \mathrm{of} \mathrm{the}$ Vedic root aorist adhāt, adhur 'he, they put'. Elsewhere (1987) I have argued that the $3 \mathrm{rd} \mathrm{pl}$. form originally had zero grade vocalism in the indicative and full grade vocalism in the injunctive, which would yield Proto-Germanic *e-dunp, *e-stunp versus *denp, *stanp. The zero grade vocalism of the reconstructed form *dunp, which is reflected in $\mathrm{OE} d y d e$, now suggests that we have to start from an augmented root aorist ${ }^{*} e-d \bar{e}$ - in Germanic. When the augment was lost, the stress was probably fixed on the initial syllable of the paradigm.

There are three weak preterits which directly reflect root aorists in Germanic (cf. Kortlandt 1989:108), viz. *kunpe- 'knew', *unpe'granted', and *wulpe- 'ruled', which are attested in Go. kunpa, OE $c \bar{u} \partial e, \bar{u} \partial e, \mathrm{ON}$ olla. These forms may be compared with Greek égnō 'perceived', onèto (for ónato) 'profited', Vedic aurta 'chose'. Here again, we may assume that the stress was fixed on the initial syllable when the augment was lost at an early stage. The historical paradigm was evidently built on the zero grade form of the root, e.g. *kununp 'they knew', *wulpa 'he chose'.

Thus, it appears that the fourth class of weak verbs originated from an extension of the athematic nasal present suffix to the zero grade stem form of the middle root aorist which had received fixed stress on the initial syllable when the augment was lost. This yields the following relative chronology:

1) loss of the augment and establishment of fixed stress on the initial syllable in the root aorist,

2) derivation of nasal presents from middle root aorists with initial stress,

3) loss of fixed stress in the root aorist and expansion of the perfect, 
4) Verner's voicing of obstruents before the stress (cf. Kortlandt 1988),

5) Kluge's nasal assimilation before the stress (cf. Kortlandt 1991),

6) Grimm's rise of new fricatives and fixation of the stress on the initial syllable (cf. Kortlandt 1988). ${ }^{1}$

Cobetstraat 24

NL-2313 KC Leiden

Note

1. It follows that I should have written *dunt instead of *dunp etc. above. As this is not the place to discuss the Proto-Germanic consonant system, I have chosen to use a more traditional transcription.

\section{References}

Kortlandt, Frederik. 1987. 'Archaic ablaut patterns in the Vedic verb'. Festschrift for Henry Hoeningswald, 219-223. Tübingen: Gunter Narr Verlag.

Kortlandt, Frederik. 1988. 'Proto-Germanic obstruents'. Amsterdamer Beiträge zur älteren Germanistik 27:3-10.

Kortlandt, Frederik. 1989. 'The Germanic weak preterit'. Amsterdamer Beiträge zur älteren Germanistik 28:101-109.

Kortlandt, Frederik. 1991. 'Kluge's law and the rise of Proto-Germanic geminates'. Amsterdamer Beiträge zur älteren Germanistik 34:1-4. 